TECHNICAL TRANSACTIONS 6/2017

CZASOPISMO TECHNICZNE /2017

CIVIL ENGINEERING

DOI: $10.4467 / 2353737$ XCT.17.097.6573

\author{
Elżbieta Szafranko (elasz@uwm.edu.pl) \\ Faculty of Geodesy, Geospatial and Civil Engineering, University of Warmia \\ and Mazury in Olsztyn
}

\title{
THE IDEA OF GRAPHIC PROFILES FOR SUPPORTING A CHOICE OF MATERIAL AND TECHNOLOGICAL SOLUTION
}

\author{
IDEA PROFILI GRAFICZNYCH PRZY WYBORZE WARIANTU ROZWIĄZAŃ \\ TECHNOLOGICZNO MATERIAEOWYCH
}

\begin{abstract}
When constructing buildings and building structures, we must often solve dilemmas regarding the implementation of specific technologies and materials. Depending on the planned use of a building, its functions and the expectations of its future users, some solutions may be superior to others. Because of a high number of factors that weigh on the final decision, it is necessary to employ efficient decision-support tools. Having analysed such a cases, the author has developed her own approach based on a graphic template of an investment project, which is compared to the profiles of assessed variants. The article presents the approach using an example of constructing a production floor building, where the ambient conditions will be harsh due to the planned production profile. The analysis included construction variants with a roof supported by one of the three types of girders: wooden, steel and prestressed concrete ones.
\end{abstract}

Keywords: building materials, investment project variants, multi-criteria methods, graphic method

\section{Streszczenie}

Realizując obiekty budowlane, niejednokrotnie musimy rozstrzygnąć dylematy dotyczące zastosowania konkretnych technologii i materiałów. W zależności od przeznaczenia obiektu, jego funkcji i oczekiwań przyszłych użytkowników różne rozwiązania mogą okazać się lepsze. Ze względu na dużą ilość czynników wplywających na ostateczny wybór konieczne jest zastosowanie sprawnych narzędzi wspomagających proces decyzyjny. Autorka, analizując podobne przypadki, wypracowała wlasną metodę postępowania opartą na graficznym szablonie inwestycji obrazującym oceny ważności kryteriów i porównaniu go z profilami ocenianych wariantów. W artykule przedstawiono sposób postępowania na przykładzie realizacji konstrukcji hali produkcyjnej, w której panują trudne warunki związane z planowaną produkcją. Analizie poddano warianty realizacji przekrycia opartego na dźwigarach, drewnianym, stalowym i żelbetowym sprężonym.

Słowa kluczowe: materiały budowlane, warianty inwestycji, metody wielokryterialne, metoda graficzna 


\section{Introduction}

The preparation for the execution of a building project typically involves an elaboration of a few solution variants. The variants are submitted to analysis in the context of technical and technological characteristics, economic aspects, working conditions during the construction process and other specific parameters. When preparing a design of a new construction, it is mandatory to comply with relevant standards and directives, technical regulations binding in the construction industry, work safety and hygiene regulations, fire protection regulations as well as many other standards and regulations, and to secure technical approvals, provide construction technical specifications and obtain administrative decisions. The costs of a construction project arise from site-specific characteristics, transportation and the need to employ qualified workers and hire specialist equipment [1]. The costs of using a raised construction can be affected, for example, by the required maintenance works. Thus, making any decision regarding a planned construction project in such a complex environment requires an efficient decision support method, which will allow us to take into consideration all significant aspects and, on the other hand, will enable us to identify a variant, which can satisfy these requirements to the highest possible degree. Because of a multitude of available methods and techniques used for analysis of variants, it is often difficult to decide which method should be chosen so as to achieve the desired effect. While selecting the most appropriate approach, it is advisable to consider such aspects as readability, quality and verifiability of achieved results and the applied mathematical apparatus $[2,11]$.

\section{Methodology of computational methods}

When selecting a particular approach to the assessment of construction and building material solutions, it is crucial to check whether the methods taken into account will correspond well to the specific nature of our project. Other important characteristics of a selected assessment method include the readability and clarity of results, the applied mathematical apparatus, easy applicability of the method, and verifiability of the results. It is also worth considering the procedure involved in the preparation of input data and the subjectivity of an assessment, the latter being a consequence of using expert opinions in most of evaluation approaches. Among numerous multi-criteria assessment methods, let us mention the Multi Criterial Evaluation (MCE), Analytic Hierarchy Process (AHP) or Indicator Method (IM) [8-11].

The underlying foundation of each of these methods is the establishment of assessment criteria, their importance and degree to which they are satisfied by subsequently evaluated solutions. Each method allows the user to take into consideration many diverse criteria. The hierarchy method enables one to divide the factors into main criteria and subcriteria, while the other two approaches assign importance to all criteria on the same level of comparison. The extent to which criteria are fulfilled by an evaluated decision variant can be identified 
by the degree of satisfying the main criteria and appropriately grouped partial criteria. Decomposition of a problem facilitates an assessment and is actually the essence of the hierarchy method. The literature provides calculation methods for all the three approaches mentioned above $[8-11]$.

\section{An example of the application of an analytical method}

To illustrate an analysis of variants, fragments of calculations for three alternative solutions of a roof girder are presented [3-7,12]. Five groups of criteria have been established, and they will serve for evaluating the alternatives in the further analytical stage:

A. Construction work criteria

A1. Ease of transportation and construction,

A2. Heavy load bearing capacity,

A3. Easy and quick assembly,

A4. Light weight of the construction,

B. Economic criteria

B1. Costs of manufacturing the element,

B2. Costs of transport,

B3. Costs of assembly and construction,

C. Environmental criteria

C1. Resistance of the construction to changeable moisture,

C2. Resistance to low temperatures,

C3. Resistance to biological corrosive factors,

C4. Fire resistance,

C5. Recyclability,

D. Maintenance criteria

D1. Resistance to blows,

D2. Easy repair and strengthening,

D3. Frequency of repairs and maintenance works,

D4. Works done to protect the construction from external factors,

E. Others

E1. Production floor accessible to large vehicles,

E2. Production process possible at low temperatures,

E3. Response to vibrations.

The importance of the main criteria and subcriteria was assessed. Their value is comprised in the $0-1$ interval. The fulfilment of individual criteria by the analysed solutions was evaluated on a $0-6$ scale, where 0 means the lack of fulfilment of a given criterion, while 6 denotes the maximum fulfilment of this criterion. The calculations are set in table 1 . Because the building for which the roof structure is to be designed will serve production purposes, high importance has been attributed to the environmental conditions in which the construction elements will work and to the maintenance conditions. 
Table 1. Specification of the weights of the main criteria and subcriteria

\begin{tabular}{|c|c|c|c|c|}
\hline Criteria & Subcriteria & Main weights & Sub-weights & Weights \\
\hline & al & 0.12 & 0.07 & 0.008 \\
\hline \multirow[t]{4}{*}{ A } & a2 & 0.12 & 0.18 & 0.022 \\
\hline & a3 & 0.12 & 0.35 & 0.042 \\
\hline & a4 & 0.12 & 0.40 & 0.048 \\
\hline & b1 & 0.14 & 0.22 & 0.031 \\
\hline \multirow[t]{3}{*}{ B } & b2 & 0.14 & 0.36 & 0.050 \\
\hline & b3 & 0.14 & 0.42 & 0.059 \\
\hline & $\mathrm{c} 1$ & 0.29 & 0.14 & 0.041 \\
\hline \multirow[t]{5}{*}{$\mathrm{C}$} & c2 & 0.29 & 0.15 & 0.044 \\
\hline & c3 & 0.29 & 0.17 & 0.049 \\
\hline & c4 & 0.29 & 0.24 & 0.070 \\
\hline & c5 & 0.29 & 0.30 & 0.087 \\
\hline & $\mathrm{d} 1$ & 0.4 & 0.11 & 0.044 \\
\hline \multirow[t]{4}{*}{$\mathrm{D}$} & $\mathrm{d} 2$ & 0.4 & 0.27 & 0.108 \\
\hline & d3 & 0.4 & 0.29 & 0.116 \\
\hline & $\mathrm{d} 4$ & 0.4 & 0.33 & 0.132 \\
\hline & e1 & 0.05 & 0.26 & 0.013 \\
\hline \multirow[t]{2}{*}{$\mathrm{E}$} & e2 & 0.05 & 0.32 & 0.016 \\
\hline & e3 & 0.05 & 0.42 & 0.021 \\
\hline
\end{tabular}

The results of our calculations suggest that the major subcriteria, which can decide upon the choice of girder structure, are the ones that identify the need for repairs and for the protection against the environmental factors that will affect adversely the roof-supporting structure $(\mathrm{d} 2, \mathrm{~d} 3, \mathrm{~d} 4)$. Table 2 contains results of our assessment of the fulfilment of these criteria by the evaluated variant solutions (v1, v2, v3).

The analysis performed as described above shows that the highest total score was achieved by the timber girder structure - w1. However, this result may not be in complete agreement with the investor's expectations because the final assessment value is affected by the points scored for the fulfilment of other, less significant criteria. For example, subcriterion $3 \mathrm{~d}$ is satisfied to the highest degree by variant 2 , which scored the lowest total number of points. Moreover, analysis of the results may be laborious and difficult due to a high number of data generated by the calculations. The complicated mathematical apparatus and, occasionally, the vagueness of calculation results may discourage investors from such analyses. During her research, the author has developed an alternative approach, based on graphic evaluation of variants supported by profiles. 
Table 2. Assessment of the evaluated variants

\begin{tabular}{|c|c|c|c|c|c|c|c|}
\hline Subcriteria & Weights & v1 & $\begin{array}{c}\text { Assessment } \\
\text { of } \mathbf{v} 1\end{array}$ & $\mathbf{v 2}$ & $\begin{array}{c}\text { Assessment } \\
\text { of } \mathbf{v} 2\end{array}$ & v3 & $\begin{array}{c}\text { Assessment } \\
\text { of } \mathbf{v} 3\end{array}$ \\
\hline al & 0.008 & 2 & 0.016 & 0.5 & 0.004 & 3 & 0.024 \\
\hline $\mathrm{a} 2$ & 0.022 & 2.5 & 0.055 & 0.7 & 0.015 & 3.5 & 0.077 \\
\hline a3 & 0.042 & 3 & 0.126 & 1 & 0.042 & 4 & 0.168 \\
\hline a4 & 0.048 & 3 & 0.144 & 2 & 0.096 & 4.5 & 0.216 \\
\hline b1 & 0.031 & 1 & 0.031 & 1 & 0.031 & 3 & 0.093 \\
\hline b2 & 0.050 & 3 & 0.150 & 2 & 0.100 & 4.5 & 0.225 \\
\hline b3 & 0.059 & 4 & 0.236 & 2.5 & 0.147 & 5 & 0.295 \\
\hline $\mathrm{cl}$ & 0.041 & 3 & 0.123 & 1.5 & 0.061 & 1 & 0.041 \\
\hline c2 & 0.044 & 3 & 0.132 & 1.5 & 0.066 & 1 & 0.044 \\
\hline c3 & 0.049 & 4 & 0.196 & 2 & 0.098 & 1.5 & 0.073 \\
\hline c4 & 0.070 & 5 & 0.350 & 2.5 & 0.175 & 2 & 0.140 \\
\hline c5 & 0.087 & 5 & 0.435 & 3 & 0.261 & 3 & 0.261 \\
\hline $\mathrm{d} 1$ & 0.044 & 2 & 0.088 & 2 & 0.088 & 1.5 & 0.066 \\
\hline $\mathrm{d} 2$ & 0.108 & 3 & 0.324 & 3 & 0.324 & 2.5 & 0.270 \\
\hline $\mathrm{d} 3$ & 0.116 & 3 & 0.348 & 4.5 & 0.522 & 3 & 0.348 \\
\hline $\mathrm{d} 4$ & 0.132 & 5 & 0.660 & 4.5 & 0.594 & 3 & 0.396 \\
\hline e1 & 0.013 & 1 & 0.013 & 0.5 & 0.007 & 1 & 0.013 \\
\hline $\mathrm{e} 2$ & 0.016 & 2 & 0.032 & 1 & 0.016 & 1.5 & 0.024 \\
\hline \multirow[t]{2}{*}{ e3 } & 0.021 & 3 & 0.063 & 1.5 & 0.032 & 1.5 & 0.032 \\
\hline & & & 3.522 & & 2.679 & & 2.806 \\
\hline
\end{tabular}

\section{Analysis according to the graphic method}

As mentioned above, time- and labour-consuming calculations frequently discourage investors and designers from certain analytical methods. Moreover, the implied necessity to analyse results in the form of a series of numbers leads to some problems while implementing the discussed assessment methods in practice. Therefore, while analyzing variants of different building material solutions in the field of civil engineering, the author has developed a new methodology based on the comparison of graphic profiles of available variants with a template of criteria for a given solution.

A template is produced by arranging main criteria in the order of increasing value of weights in groups of main criteria. The subcriteria are ordered according to the same principle. 
In the case discussed in this paper, the order was determined in accordance to the assigned weights: $\mathrm{A}-0.12, \mathrm{~B}-0.14, \mathrm{C}-0.29$ and $\mathrm{D}-0.4$, followed by other criteria specific for the circumstances surrounding each specific design. Table 3 shows the subcriteria arranged according to the same principle, while fig. 1 illustrates the achieved template of criteria.

The next step is to evaluate variant solutions and to construct profiles for each analysed variant. The data should be arranged according to the order assumed for the template. In our case, we are expected to evaluate three possible solutions for building roof girders: timber, prestressed concrete and steel structures. The assessment of these variants is presented in table 4, while the templates and profiles are illustrated in Fig. 1, 2, 3 and 4.

Table 3. Data for elaboration of a template of criteria

Table 4. Assessment of the variants

\begin{tabular}{|c|c|c|}
\hline Criteria & Subcriteria & Weights \\
\hline & a1 & 0.008 \\
\hline \multirow[t]{4}{*}{$\mathrm{a}$} & a2 & 0.022 \\
\hline & a3 & 0.042 \\
\hline & a4 & 0.048 \\
\hline & b1 & 0.031 \\
\hline \multirow[t]{3}{*}{$\mathrm{b}$} & b2 & 0.050 \\
\hline & b3 & 0.059 \\
\hline & $\mathrm{cl}$ & 0.041 \\
\hline \multirow[t]{5}{*}{ c } & c2 & 0.044 \\
\hline & c3 & 0.049 \\
\hline & c4 & 0.070 \\
\hline & c5 & 0.087 \\
\hline & $\mathrm{d} 1$ & 0.044 \\
\hline \multirow[t]{4}{*}{$\mathrm{d}$} & $\mathrm{d} 2$ & 0.108 \\
\hline & d3 & 0.116 \\
\hline & $\mathrm{d} 4$ & 0.132 \\
\hline & e1 & 0.013 \\
\hline \multirow[t]{2}{*}{ e } & $\mathrm{e} 2$ & 0.016 \\
\hline & e3 & 0.021 \\
\hline
\end{tabular}

\begin{tabular}{|c|c|c|c|}
\hline Subcriteria & $\mathbf{v 1}$ & v2 & v3 \\
\hline a1 & 0.016 & 0.004 & 0.024 \\
\hline $\mathrm{a} 2$ & 0.055 & 0.015 & 0.077 \\
\hline a3 & 0.126 & 0.042 & 0.168 \\
\hline $\mathrm{a} 4$ & 0.144 & 0.096 & 0.216 \\
\hline b1 & 0.031 & 0.031 & 0.093 \\
\hline b2 & 0.150 & 0.100 & 0.225 \\
\hline b3 & 0.236 & 0.148 & 0.295 \\
\hline $\mathrm{cl}$ & 0.123 & 0.062 & 0.041 \\
\hline c2 & 0.132 & 0.066 & 0.044 \\
\hline c3 & 0.196 & 0.098 & 0.073 \\
\hline$c 4$ & 0.350 & 0.175 & 0.140 \\
\hline$c 5$ & 0.435 & 0.261 & 0.261 \\
\hline $\mathrm{d} 1$ & 0.088 & 0.088 & 0.066 \\
\hline $\mathrm{d} 2$ & 0.324 & 0.324 & 0.270 \\
\hline d3 & 0.348 & 0.522 & 0.348 \\
\hline $\mathrm{d} 4$ & 0.660 & 0.594 & 0.396 \\
\hline e1 & 0.013 & 0.006 & 0.013 \\
\hline e2 & 0.032 & 0.016 & 0.024 \\
\hline e3 & 0.063 & 0.031 & 0.032 \\
\hline
\end{tabular}

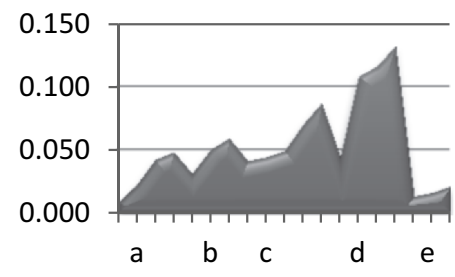

Fig. 1. Template of criterion

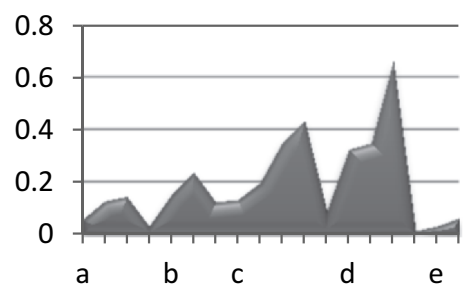

Fig. 2. Profile of variant 1 


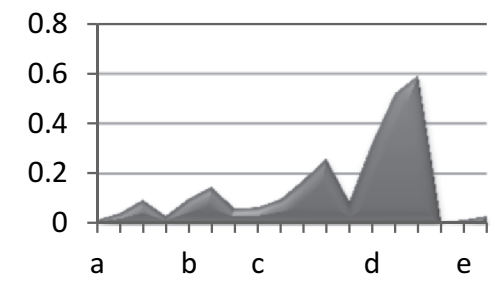

Fig. 3. Fig. 3. Profile of variant 2

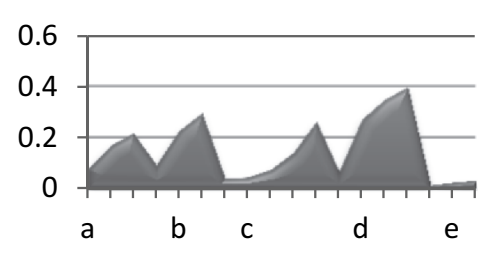

Fig. 4. Profile of variant 3

Once the shapes of the profiles are compared, we can deduce that the profile of variant 1 is in the best agreement with the template of the criteria. This conclusion confirms the result achieved by the calculation method presented earlier. In addition, it lets us take into account the specific features of the solution and, following the comparison of the profiles, it enables us to evaluate the most important characteristics of the variants. Analysis of the graphic profiles of solutions is simpler, more user-friendly and generates more trustworthy results. Moreover, comparative analysis of the graphic similarity of profiles can be performed with software that can calculate probability percentages.

\section{Summary and analysis of the results}

In the process of preparing oneself for the construction of building structures, it is extremely important to analyse various variants of an investment project. One of the problems that a designer faces is to select structural and building material solutions. Analysis of available technologies should involve a decision-support method.

The model approach presented above shows a possible application of the graphic method, based on multi-criteria assessment methodology, for the evaluation of several alternative variants. The graphic method, prepared in the form of profiles for all variants subsequently compared with a template of criteria, is the most user-friendly approach to the interpretation of results obtained through a multi-criteria analysis. Ready-made profiles, which can be used by architects, designers and investors, are met with a warm reception in the world of engineers.

\section{References}

[1] Dziadosz A., Kończak A., Review of selected methods of supporting decision-making process in the construction industry, "Archives of Civil Engineering" 62(1), 2016, 111-126.

[2] Foley CM., Schinler D., Automated design of steel frames using advanced analysis and object-oriented evolutionary computation, "Journal of Structural Engineering” 129(5), 2003, 648-660. 
[3] Frühwald E., Serrano E., Toratti T., Emilsson A., Thelandersson S., Design of safe timber structures-how can we learn from structural failures in concrete, steel and timber? Report TVBK-3053, Lund 2007.

[4] Gencturk B., Hossain K., Kapadia A., Labib E., Mo Y., Use of digital image correlation technique in full-scale testing of prestressed concrete structures, "Measurement" (47), 2014, 505-515.

[5] Haughian CP., Improvement in composite metallic girders, U.S. Patent No. 183,(160), 10 Oct. 1876.

[6] Konczak A., Paslawski J., Decision Support in Production Planning of Precast Concrete Slabs Based on Simulation and Learning from Examples, "Procedia Engineering" (122), 2015, 81-87.

[7] Libby JR., Modern prestressed concrete: design principles and construction methods, "Springer Science \& Business Media”, 2012.

[8] Szafranko E., Methodology of the assessment of investment project variants based on multicriteria analyses, QUAESTI-Virtual Multidisciplinary Conference, (1), 2015.

[9] Szafranko E., Ways to determine criteria in multi-criteria methods applied to assessment of variants of a planned building investment, "Czasopismo Techniczne" 2-B/2014, 41-48.

[10] Szafranko E., Application of the analytic hierarchy process (AHP) to evaluation of variants of a planned road investment project, "Journal of International Scientific Publications: Materials, Methods \& Technologies” 7(1), 2013, 152-163.

[11] Walker A.. Project management in construction, John Wiley \& Sons, 2015.

[12] Wilby CB., Structural Concrete: Materials; Mix Design; Plain, Reinforced and Prestressed Concrete, Design Tables, Elsevier, 2013. 